\title{
Influence of incubation conditions on the anoxic survival of marine bivalves. Static and semi-static incubations
}

\author{
Albertus de Zwaan ${ }^{1, *}$, Otello Cattani $^{2}$, Giovanni Vitali $^{2}$, Paolo Cortesi $^{2}$ \\ ${ }^{1}$ Netherlands Institute of Ecology, Centre for Estuarine and Coastal Ecology, PO Box 140, \\ 4400 AC Yerseke, The Netherlands \\ ${ }^{2}$ Department of Biochemistry, Veterinary Section, University of Bologna, Via Tolara di sopra 50, \\ 40064 Ozzano Emilia (Bologna), Italy
}

\begin{abstract}
In a comparative study of 4 bivalve species we show that the apparent widely different tolerances in survival time observed in a closed system filled with $\mathrm{N}_{2}$-gassed seawater is mainly due to the experimental conditions. Both a high dose of cadmium and the antibiotic chloramphenicol increase survival time 2- to 4 -fold. Without precautions for bacterial growth, the survival time of the most tolerant species, Scapharca inaequivalvis, is about 4 times longer than that of the most sensitive species, Venus gallina. The other bivalves Tapes philippinarum and Mytilus galloprovincialis, have intermediate survival times. When proliferation of bacteria is prevented by chloramphenicol, the survival time of $S$. inaequivalvis remains the highest; however under these conditions the other 3 species show similar survival times. Bacteria cause a drop in $\mathrm{pH}$ of the incubation medium and the accumulation of sulphide. S. inaequivalvis exhibits a significant decrease in survival time in the presence of exogenous sulphide. The antibiotic postpones the accumulation of sulphide, but a significant population of sulphate-reducing bacteria is able to survive in its presence. In the case of V. gallina and $M$. galloprovincialis, exogenous sulphide (up to $400 \mu \mathrm{M}$ ) does not affect the improved survival time due to the antibiotic. This holds also for a decrease in $\mathrm{pH}$. Bacterial toxins other than sulphide or direct action on the integrity of the organism must be responsible for the adverse effects on survival. The responsible micro-organisms are associated with the bivalves, and anoxia induces their proliferation. For this reason, accumulation of bacterial noxious products cannot be avoided by frequent renewal of the medium.
\end{abstract}

KEY WORDS: Benthic macrofauna - Bivalves · Hydrogen sulphide - Anaerobiosis · Cadmium · Chloramphenicol · Anoxic resistance

\section{INTRODUCTION}

Several studies have shown that exposure of bivalves to contaminants dissolved or suspended in seawater reduce their survival in air or in anoxic seawater. Anoxic survival is used in monitoring programmes to assess environmental toxicity (Eertman \& de Zwaan 1994). However, studies on the uptake of the

\footnotetext{
*E-mail: zwaan@cemo.nioo.knaw.nl
}

heavy metals $\mathrm{Cd}, \mathrm{Cu}$ and $\mathrm{Hg}$ by bivalves and the effect of toxin accumulation on anaerobic energy metabolism and anoxic survival obtained unexpected results (Weber 1990, Weber et al. 1990, 1992, Cortesi et al. 1992, de Zwaan et al. 1995). We exposed the bivalves in well-aerated seawater to metal concentrations at which mortality within 1 mo was not (or only slightly) higher than in untreated control individuals. At relatively low doses of $\mathrm{Cd}$ and $\mathrm{Hg}$, we observed the expected negative effects on anoxic survival time. 
However, when bivalves were introduced to anoxic seawater after exposure to relatively high doses of these metals, their survival times appeared to be substantially longer than that of controls. This was also the case when untreated bivalves were exposed to high concentrations of heavy metals during the anoxic incubation. Shell-valve blackening was observed in the controls, but was virtually absent in the presence of these toxins. Apparently the relatively high doses of the metals affected bacteria (causing this blackening) more than the metabolically affected bivalves. This 'bacteriostatic' effect was not only able to reverse the toxic effect of the metals, but also benefited the bivalves under anoxic stress. We realised that the median survival times estimated in static anoxic systems might underestimate the potential of these bivalves to survive anoxic conditions.

In the Adriatic Sea, populations of 2 bivalve species of great commercial importance, the 'vongole' Venus gallina and the blue mussel Mytilus galloprovincialis, are sharply decreasing, whereas populations of the recently introduced blood clam Scapharca inaequivalvis, a native of the Indo-Pacific region, are rapidly increasing and out-competing the 2 native species (Ghisotti \& Rinaldi 1976). In order to compensate for the demise of the 2 native species, fish farms have imported the Japanese littleneck Tapes philippinarum. Over the last $10 \mathrm{yr}$ we have been carrying out an extensive analysis of the physiological and biochemical responses to low oxygen exposure by these 4 species (Brooks et al. 1991, de Zwaan et al. 1991, Thillart et al. 1992). We have concluded that the high tolerance of $S$. inaequivalvis against anoxia explains, in part, the success of this species over the others. However, we derived our survival data from individuals sealed in closed jars, whereby bacterial interference may have led to misleading results. We therefore decided to reinvestigate the anoxic survival times of these species, taking precautions against bacterial growth.

In a closed incubation system without water renewal, frequent handling of the bivalves is minimal, but with long survival times, changes in the incubation medium may occur which adversely affect anoxic survival (Felder 1979, Llansó \& Diaz 1994). Several euryoxic invertebrates excrete metabolic compounds (e.g. volatile fatty acids, ethanol), others expel their gut contents when subjected to anaerobic conditions (de Zwaan \& Skjoldal 1979). Fermentation products as well as excrements may provide substrates for the development of micro-organisms. Blackening of the body wall of worms and shells of bivalves kept in anoxic water points to the generation of sulphide, indicating microbial activity (Oeschger \& Theede 1988). A negative effect of exogenous sulphide on anoxic survival time has been observed for a large number of invertebrates, whereas others appear to be insensitive (de Zwaan \& Eertman 1996, Gamenick et al. 1996, Jahn \& Theede 1997). Unfortunately, spontaneous generation of sulphide in control individuals that may mask negative effects in the sulphide-exposed groups has, in general, not been considered.

The same holds for many studies dealing with effects of sulphide on metabolism. Artefacts in metabolic studies caused by proliferation of bacteria in anoxic medium have been reported. Frank (1983) observed that addition of antibiotics prevented the decomposition of ethanol and acetate by micro-organisms excreted by Chironomus plumosus larvae. Oeschger (1990) assumed that the low values for propionate in the incubation medium after long-term anaerobiosis of the bivalve Astarte borealis were a result of bacterial degradation. De Zwaan et al. (1982) detected large quantities of ammonia and acetate in in vitro incubation of adductor muscle of the blue mussel Mytilus edulis which was not observed in vivo incubation. Hummel et al. (1989) observed high acetic acid levels in the extrapallial water of emersed mussels and cockles at a time when mortality accelerated, which could only partly be accounted for by the amount of glycogen metabolised.

In order to gain better insight into how microbial activity may influence survival times, we examined for 4 bivalve species the effect of a high dose of cadmium and of the addition of the antibiotic chloramphenicol upon changing from aerated to anoxic seawater. We focussed on the role that acidification and sulphide generation, both indicators of microbial proliferation, may play on survival, and whether these effects could be counteracted by frequent renewal of the incubation medium.

\section{MATERIALS AND METHODS}

Individuals. Infaunal Scapharca inaequivalvis and Venus gallina were dredged from ca $10 \mathrm{~m}$ depth a few miles offshore near Cesenatico in the Adriatic Sea, Italy. Unless stated otherwise, the sediment at the collection side was sandy. Infaunal Tapes philippinarum and off-bottom, rope-cultured Mytilus galloprovincialis were obtained from a fish farm at Goro (province of Ferrara). The bivalves were placed in open baskets suspended in 30001 polyester tanks of sand-filtered seawater at the Institute of Cesenatico. The water was well aerated and maintained at ambient seawater temperature by equilibration with the air-conditioned aquarium room. The seawater was pumped in from an inlet about $300 \mathrm{~m}$ offshore into a large concrete basin for sedimentation prior to filtering. Every second day, about $20 \%$ of the water was exchanged. Unless stated 
otherwise, bivalves were used in the experiments $1 \mathrm{wk}$ after collection. Anoxic survival was always determined at ambient seawater temperature at the start of the experiment. Unless stated otherwise, illumination was according to the ambient daily cycle.

Protocol of experiments. Anoxic seawater was prepared by vigorously bubbling natural sand-filtered seawater for about $2 \mathrm{~h}$ with $\mathrm{N}_{2}$ directly into the incubation flasks or into reservoirs. The latter method was applied in the case of small incubation flasks and when compounds (sulphide, chloramphenicol, Tris) had to be added. From the reservoirs, the flasks were filled while being flushed with $\mathrm{N}_{2}$. Chloramphenicol, $\mathrm{CdCl}_{2}$ (source of cadmium) and Tris were added as dry powder, and $\mathrm{Na}_{2} \mathrm{~S}$ (the source of sulphide) from a stock solution of $200 \mathrm{mmol} \mathrm{l}^{-1}$. The stock solution was made by adding washed crystals of $\mathrm{Na}_{2} \mathrm{~S} \times 9 \mathrm{H}_{2} \mathrm{O}$ to $\mathrm{N}_{2}$-saturated distilled water. After additions, the $\mathrm{pH}$ was adjusted with $\mathrm{HCl}$ to match the values of the control anoxic seawater. The flasks were tightly closed with glass stoppers. The oxygen concentration after filling was $<0.15 \mathrm{mg} \mathrm{l}^{-1}$ (Winkler method). Salinity was 32 to $34 \mathrm{psu}$. No food was added. Except for 1 experiment (later subsection 'Chloramphenicol and Tris') the experimental bivalves covered part of the bottom of the flasks in 1 layer part. The biomass volume with closed shell valves was $19.55 \pm 1.72,2.43 \pm 0.22,5.53 \pm 0.28$ and $15.16 \pm 1.68 \mathrm{ml}$ for Scapharca inaequivalvis, Venus gallina, Tapes philippinarum and Mytilus galloprovincialis, respectively. Mortality was assessed by failure of constriction upon touching the mantle edge.

Throughout this paper, the terms sulphide and $\mathrm{H}_{2} \mathrm{~S}$ refer to total sulphide, and the term Tris to the buffer Tris (hydroxymethyl)-aminomethane.

Cadmium. Scapharca inaequivalvis was either collected from muddy sediment (October, $17^{\circ} \mathrm{C}$ ) or sandy sediment (November, $11^{\circ} \mathrm{C}$ ). Venus gallina was collected from sandy sediment (end of September, $18^{\circ} \mathrm{C}$ ). Upon arrival, some of the $S$. inaequivalvis collected from the sandy sediment were exposed for $2 \mathrm{wk}$ to well-aerated seawater containing $100 \mu \mathrm{g} \mathrm{Cd} \mathrm{l}^{-1}$ at $11^{\circ} \mathrm{C}$, and anoxic survival was subsequently estimated. The remaining $S$. inaequivalvis and V. gallina were kept in the aquarium for $2 \mathrm{wk}$ prior to experimentation. S. inaequivalvis and $V$. gallina were then subdivided into an untreated control group and a group subjected to a high dose of cadmium $\left(500 \mu \mathrm{g} \mathrm{Cd} \mathrm{l}^{-1}\right)$ dissolved in anoxic seawater. S. inaequivalvis was incubated anoxically at $11^{\circ} \mathrm{C}$ and $\mathrm{V}$. gallina at $18^{\circ} \mathrm{C}$. Two wk after collection, $S$. inaequivalvis from the muddy sediment were treated in a similar way at $17^{\circ} \mathrm{C}$. In all cases, anoxic survival was determined for 50 individuals incubated in 41 (S. inaequivalvis) or 21 ( $V$. gallina) flasks, each containing 16 to 17 individuals. The incubation medium was changed every day, and mortality was checked. Dead individuals were removed.
Changes in incubation water. Fifty specimens of Venus gallina were put in 21 flasks filled with anoxic seawater at $18^{\circ} \mathrm{C}$. Samples were taken daily to measure the concentration of ammonia, sulphide and the $\mathrm{pH}$ of the incubation water. The incubation water was not changed during the experiment. Dead individuals were removed from the flasks and registered for estimation of median survival time.

Chloramphenicol and sulphide. The effect of sulphide on the anoxic resistance of Scapharca inaequivalvis and Venus gallina was examined at $18^{\circ} \mathrm{C}$ by addition of $0.2 \mathrm{mmol} \mathrm{l}^{-1} \mathrm{H}_{2} \mathrm{~S}$ and $3 \mathrm{mg} \mathrm{l}^{-1}$ chloramphenicol to the anoxic water. The controls contained only $3 \mathrm{mg} \mathrm{l}^{-1}$ chloramphenicol. Other details were as described for the cadmium experiments.

Chloramphenicol and Tris. The effect of the antibiotic chloramphenicol and $\mathrm{pH}$ buffering by Tris on the anoxic resistance of Scapharca inaequivalvis, Venus gallina, Tapes philippinarum and Mytilus galloprovincialis was determined. At the start of the experiment, 48 (V. gallina) or 24 (all other species) specimens were added to anoxic medium in $1.5 \mathrm{l}$ dark-brown glass bottles. The following media were used: (1) filtered anoxic seawater; (2) filtered anoxic seawater with the addition of $3 \mathrm{mmol} \mathrm{l}^{-1}$ Tris; (3) filtered anoxic seawater with the addition of $5 \mathrm{mg} \mathrm{l}^{-1}$ chloramphenicol; (4) filtered anoxic seawater with the addition of both $3 \mathrm{mmol} \mathrm{l}^{-1}$ Tris and $5 \mathrm{mg} \mathrm{l}^{-1}$ chloramphenicol. The $\mathrm{pH}$ was adjusted to $\sim 8$, the $\mathrm{pH}$ of the deoxygenated seawater. The bottles were held in the dark. The media were changed every $24 \mathrm{~h}$ and dead individuals were removed. Sulphide concentration and $\mathrm{pH}$ were regularly determined. The temperature was kept at $18^{\circ} \mathrm{C}$.

Effect of chloramphenicol in the presence of Tris buffer and sulphide. In this experiment, the anoxic medium of both the control and the experimental groups contained initially about $0.4 \mathrm{mM} \mathrm{H}_{2} \mathrm{~S}$ and $20 \mathrm{mM}$ Tris. The $\mathrm{pH}$ of the incubation medium was adjusted to 8.0 at the begin of the experiment. Chloramphenicol $\left(5 \mathrm{mg} \mathrm{l}^{-1}\right)$ was also added to the experimental group at the beginning of the experiment and at $7 \mathrm{~d}$ intervals thereafter. The bivalves were placed in 4 l flasks at $18^{\circ} \mathrm{C}$; the flasks contained 24 specimens of Venus gallina, or 8 specimens of Scapharca inaequivalvis or Mytilus galloprovincialis (in duplicate). Survival was checked daily, and the water was not renewed. $\mathrm{H}_{2} \mathrm{~S}$ concentration was frequently determined, and $\mathrm{pH}$ was checked after $1 \mathrm{wk}$ and near the end of the experiment (Day 22). Two flasks without bivalves were filled with the medium of the control and experimental groups.

Determination of sulphide, ammonia and pH. Sulphide was determined after Svenson (1980) and ammonia after Truesdale (1971). The $\mathrm{pH}$ was measured using a Radiometer PHM $82 \mathrm{pH}$ meter with a sulphide-insensitive electrode. 
Statistics. The non-parametric Kaplan-Meier test was used to estimate log-rank and Wilcoxon values for comparing the survival curves (Kaplan \& Meier 1958). A confidence limit of $95 \%$ was used to test the significance of differences between groups. $\mathrm{LT}_{50}$ values (median survival times) were estimated using the trimmed Spearman-Karber method $(\alpha=10 \%)$ (Hamilton et al. 1977). In the case of replicates, results were pooled for the calculation of $\mathrm{LT}_{50}$ and for comparing survival curves.

\section{RESULTS}

\section{Cadmium}

Exposure to $100 \mu \mathrm{g} \mathrm{Cd}^{-1}$ for $2 \mathrm{wk}$ prior to incubation in Cd-free anoxic seawater caused a significant decrease in the anoxic survival time of Scapharca inaequivalvis. $\mathrm{LT}_{50}\left(11^{\circ} \mathrm{C}\right)$ of cadmium-exposed and control clams from the sandy sediment were 23.0 and $27.6 \mathrm{~d}$, respectively (Fig. 1: upper graph). Surprisingly, acute exposure of $S$. inaequivalvis collected from the muddy

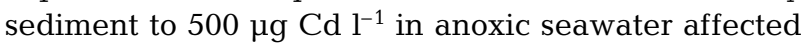
the survival time positively. $\mathrm{LT}_{50}$ values $\left(17^{\circ} \mathrm{C}\right)$ of the controls and cadmium-treated group were 16.1 and 27.3 d, respectively (Fig. 1: lower graph). After a few
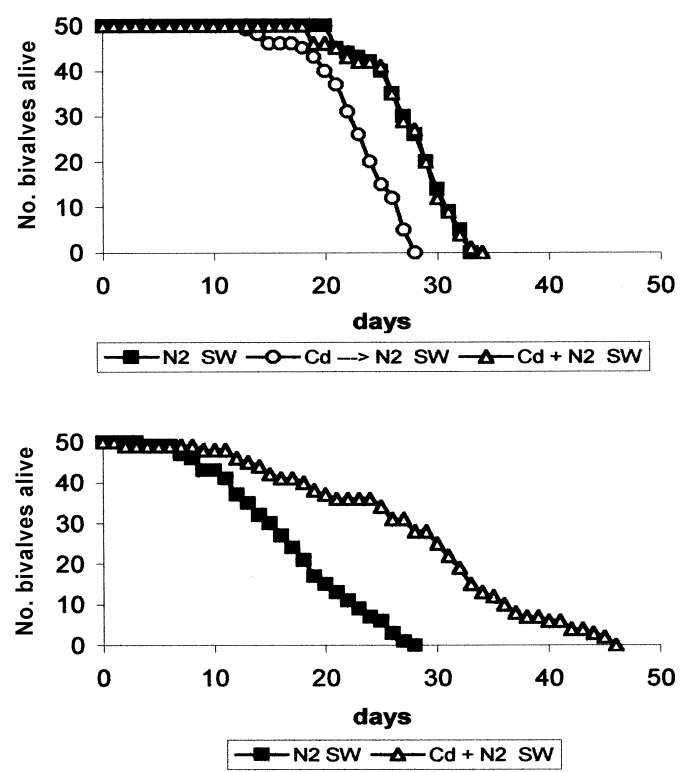

Fig. 1. Scapharca inaequivalvis. Survival in anoxic seawater of controls ( $\mathrm{N}_{2}$ plus seawater, $\mathrm{N} 2 \mathrm{SW}$ ) and cadmium (500 ppb)exposed $(\mathrm{Cd}+\mathrm{N} 2 \mathrm{SW})$ bivalves collected from sandy (upper graph) and muddy sediments (lower graph). 'Sandy' clams were also exposed to cadmium (100 ppb) for $2 \mathrm{wk}$ prior to anoxic incubation $(\mathrm{Cd} \rightarrow \mathrm{N} 2 \mathrm{SW}$ : upper graph). The media were changed every $24 \mathrm{~h}$; 'sandy' clams were incubated at $11^{\circ} \mathrm{C}$, 'muddy' clams at $17^{\circ} \mathrm{C}$ days, the shells of the control group gradually changed colour from grey to black, while the cadmium-treated group retained their natural yellowish colour. However, $S$. inaequivalvis dredged from sandy sediment did not benefit from the presence of cadmium. There was no significant difference between the survival curves of the control and experimental groups. The $\mathrm{LT}_{50}\left(11^{\circ} \mathrm{C}\right)$ for these groups was 27.6 and 27.7, respectively (Fig 1: upper graph). Towards the end of the experiment, the shells of the controls were only slightly darker than that of Cd-treated groups. On the other hand, Venus gallina collected from sandy sediment benefited from the presence of cadmium in anoxic seawater, as demonstrated by an increase in the $\mathrm{LT}_{50}$ value $\left(18^{\circ} \mathrm{C}\right)$ from 3.4 to $7.6 \mathrm{~d}$ (Fig 2$)$. The control individuals developed a grey precipitate on their shell valves after the third day, while the Cd-treated individuals were seemingly unchanged.

\section{Changes in incubation water}

In this experiment, the median survival time of Venus gallina was 6.3 days (Fig. 3). There was a rapid increase of ammonia and sulphide in the incubation water, especially in the final stage, when mortality increased rapidly. At Day 6, there was $1.24 \mathrm{mmol} \mathrm{l}^{-1}$ ammonia and $0.31 \mathrm{mmol} \mathrm{H}_{2} \mathrm{~S} \mathrm{l}^{-1}$ in the water (Fig. 3: upper graph). During the incubation period, the $\mathrm{pH}$ dropped by about 2 units (Fig. 3: lower curve in bottom graph).

\section{Chloramphenicol and sulphide}

Chloramphenicol was added to prevent biotic sulphide formation. For both Scapharca inaequivalvis and Venus gallina, survival time was prolonged by addition of chloramphenicol. In the previous experiments we obtained $\mathrm{LT}_{50}$ values $\left(18^{\circ} \mathrm{C}\right)$ for $V$. gallina of 3.4

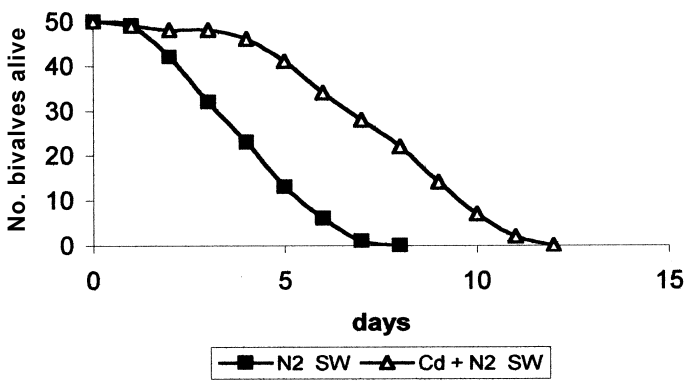

Fig. 2. Venus gallina. Survival in anoxic seawater of controls (N2 SW) and cadmium (500 ppb)-exposed (Cd+N2 SW) bivalves. The media were changed every $24 \mathrm{~h}$. Temperature was $18^{\circ} \mathrm{C}$ 


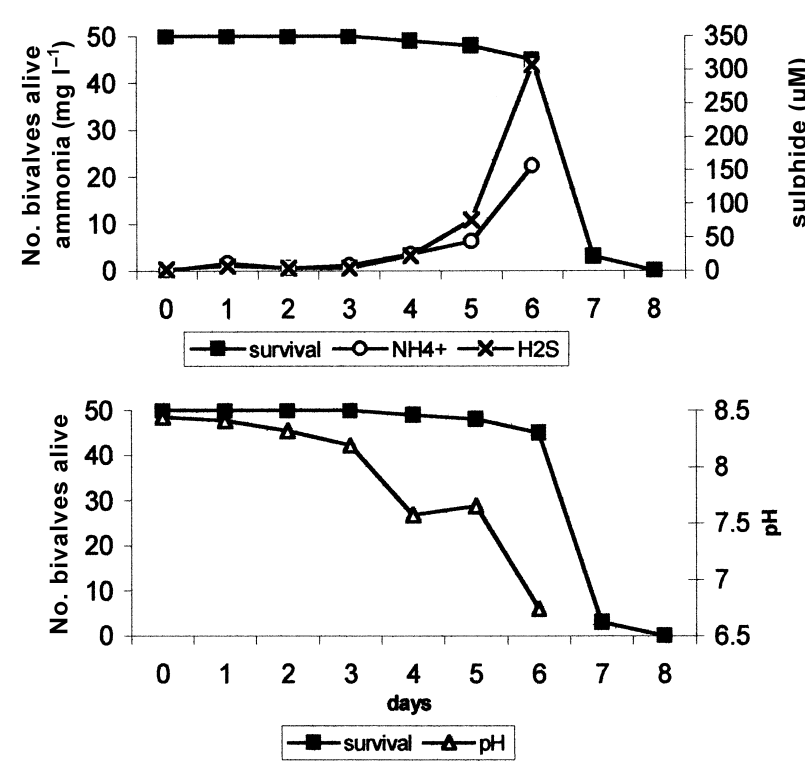

Fig. 3. Venus gallina. Anoxic survival (both graphs), accumulation of ammonia and sulphide (upper graph) and drop in $\mathrm{pH}$ (lower graph) in the anoxic seawater containing V. gallina. The incubation medium was not changed during the experiment; temperature was $18^{\circ} \mathrm{C}$

(Fig. 2) and 6.3 d (Fig. 3), compared with $16.2 \mathrm{~d}$ (chloramphenicol minus exogenous sulphide) in this experiment. Also, a strong effect of the antibiotic was observed with $S$. inaequivalvis ( $\mathrm{LT}_{50}$ values from $16.1 \mathrm{~d}$ at $17^{\circ} \mathrm{C}$ to 28.2 at $18^{\circ} \mathrm{C}$, Figs. $1 \& 4$, respectively).

The addition of $0.2 \mathrm{mmol} \mathrm{H}_{2} \mathrm{~S}^{-1}$ to the anoxic seawater did not have a significant adverse effect on anoxic survival time for Venus gallina. Like the controls, $50 \%$ mortality was reached at about $16 \mathrm{~d}$ (Fig. 4). Simultaneous exposure of Scapharca inaequivalvis to anoxia and sulphide resulted in significantly lower $\mathrm{LT}_{50}$ values (18.6 d) in comparison to controls (28.2 d) (Fig. 4). The rapid blackening of shells of both species when sulphide was added was remarkable. In the blood clam, the gills were also noticeably blackened after half a day.

\section{Chloramphenicol and Tris}

In this comparative study, the 4 bivalve species showed widely different tolerances to lack of oxygen (Fig. 5). In anoxic seawater without additions (Medium 1), Venus gallina showed by far the lowest survival: anoxic survival time of the most tolerant species, the blood clam Scapharca inaequivalvis, expressed as $\mathrm{LT}_{50}$, was about 4.5 times longer. The anoxic survival times of Mytilus galloprovincialis and Tapes philippinarum were intermediate. The addition of the antibi-
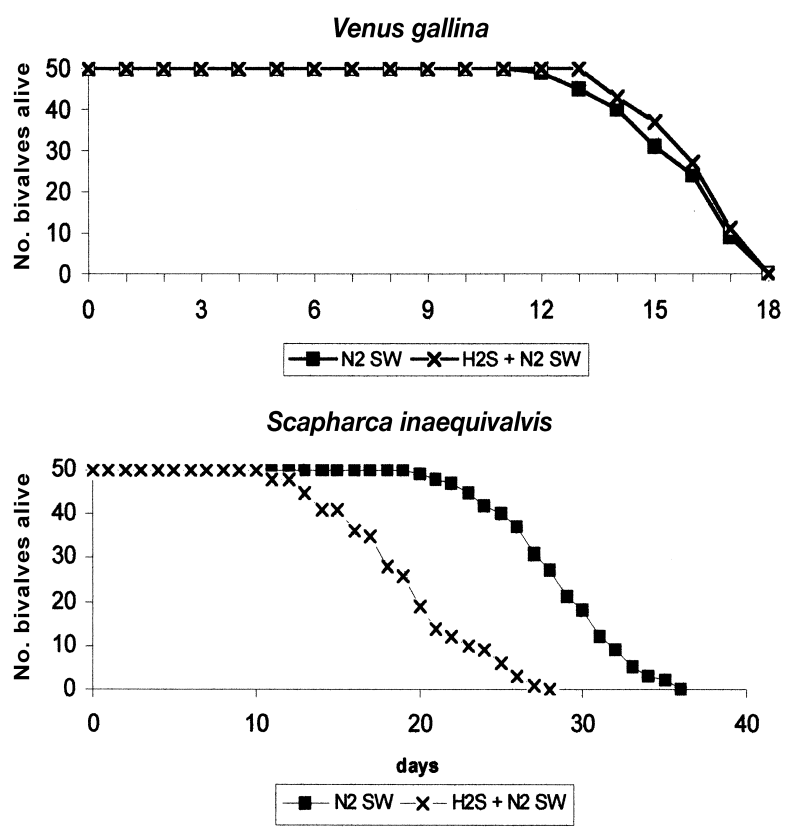

Fig. 4. Venus gallina and Scapharca inaequivalvis. Survival in anoxic seawater containing chloramphenicol of controls (N2 SW) and sulphide (H2S + N2SW)-exposed bivalves. The incubation media were changed every $24 \mathrm{~h}_{\text {i }}$ temperature was $18^{\circ} \mathrm{C}$

otic chloramphenicol (Media 3 and 4 ) led to a $\sim 4$-fold increase in survival time for $V$. gallina and a $\sim 2$ - to 3 fold increase for the other species (Table 1, Fig. 5).

For all species, progressively increasing levels of sulphide could be detected in the incubation media without chloramphenicol with increasing incubation time, despite the fact that the medium was changed daily and dead individuals removed. This coincided with a gradual blackening of the shells. The accumulation of sulphide was strongest in Scapharca inaequivalvis, in which it exceeded the other species by at least 1 order of magnitude. The addition of chloramphenicol mar-

Table 1. Scapharca inaequivalvis, Venus gallina, Tapes philippinarum and Mytilus galloprovincialis. Effect of chloramphenicol (CA) in the presence or absence of Tris (3 mM) on $\mathrm{LT}_{50}$ values (d) of 4 bivalve species. Superscripts indicate comparison of corresponding survival curves; those with letters in common are significantly different at $\mathrm{p}<0.05$

\begin{tabular}{|lcccc|}
\hline \multirow{2}{*}{ Species } & \multicolumn{2}{c}{ Tris } & \multicolumn{2}{c|}{ No Tris } \\
& $+\mathrm{CA}$ & $-\mathrm{CA}$ & $+\mathrm{CA}$ & $-\mathrm{CA}$ \\
\hline S. inaequivalvis & $33.9^{\mathrm{a}}$ & $17.0^{\mathrm{b}}$ & $36.1^{\mathrm{a}}$ & $14.7^{\mathrm{b}}$ \\
V. gallina & 15.0 & 3.7 & 15.1 & 3.3 \\
T. philippinarum & 17.0 & 6.2 & 16.3 & 6.6 \\
M. galloprovincialis & 20.8 & 9.3 & 19.5 & 9.8 \\
\hline
\end{tabular}



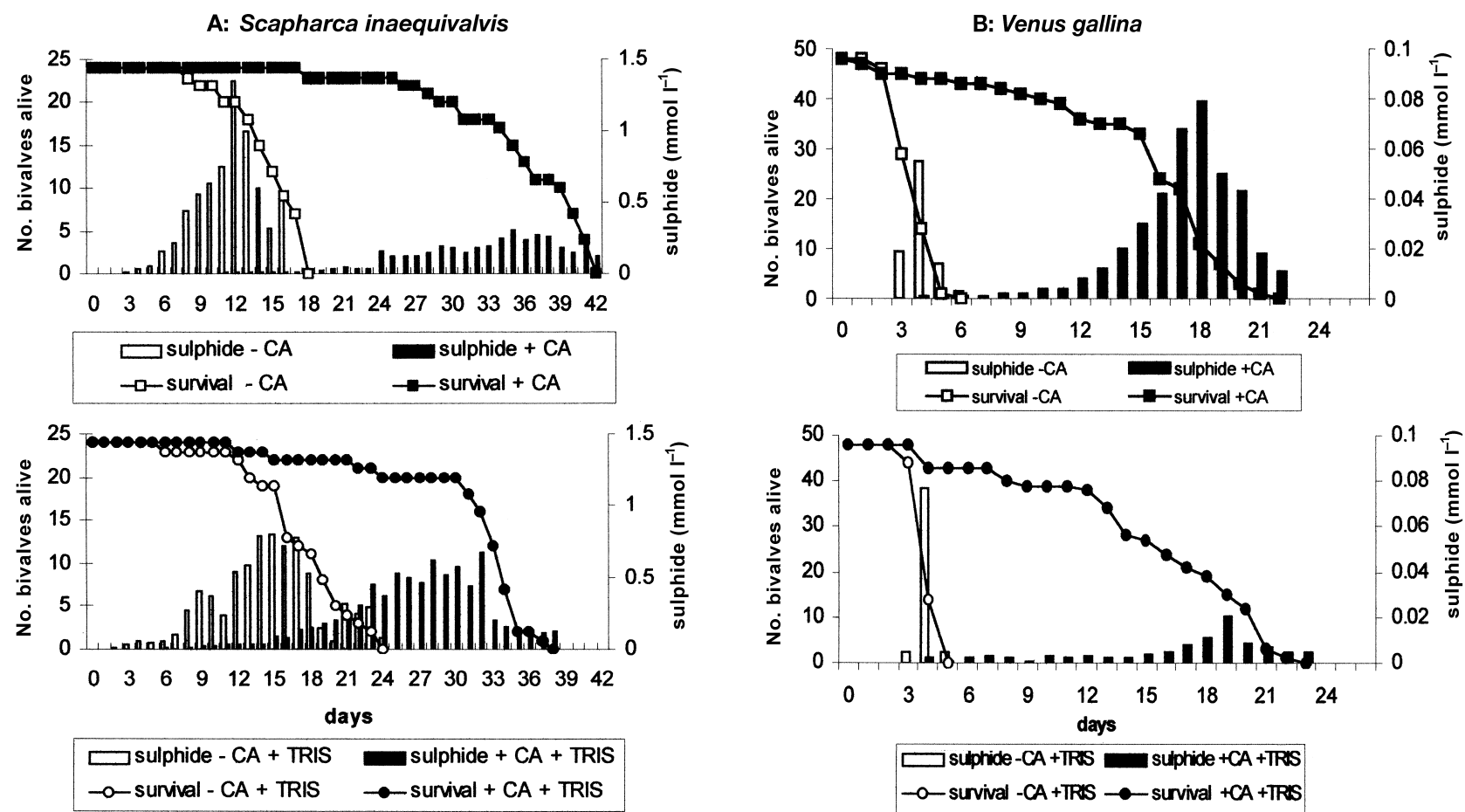

\section{$\square$ sulphide $-C A+T R S S$ suphide +CA + TRS}

$\rightarrow$ - survival $-C A+T R$ S $\rightarrow$ survival $+C A+T R$ S
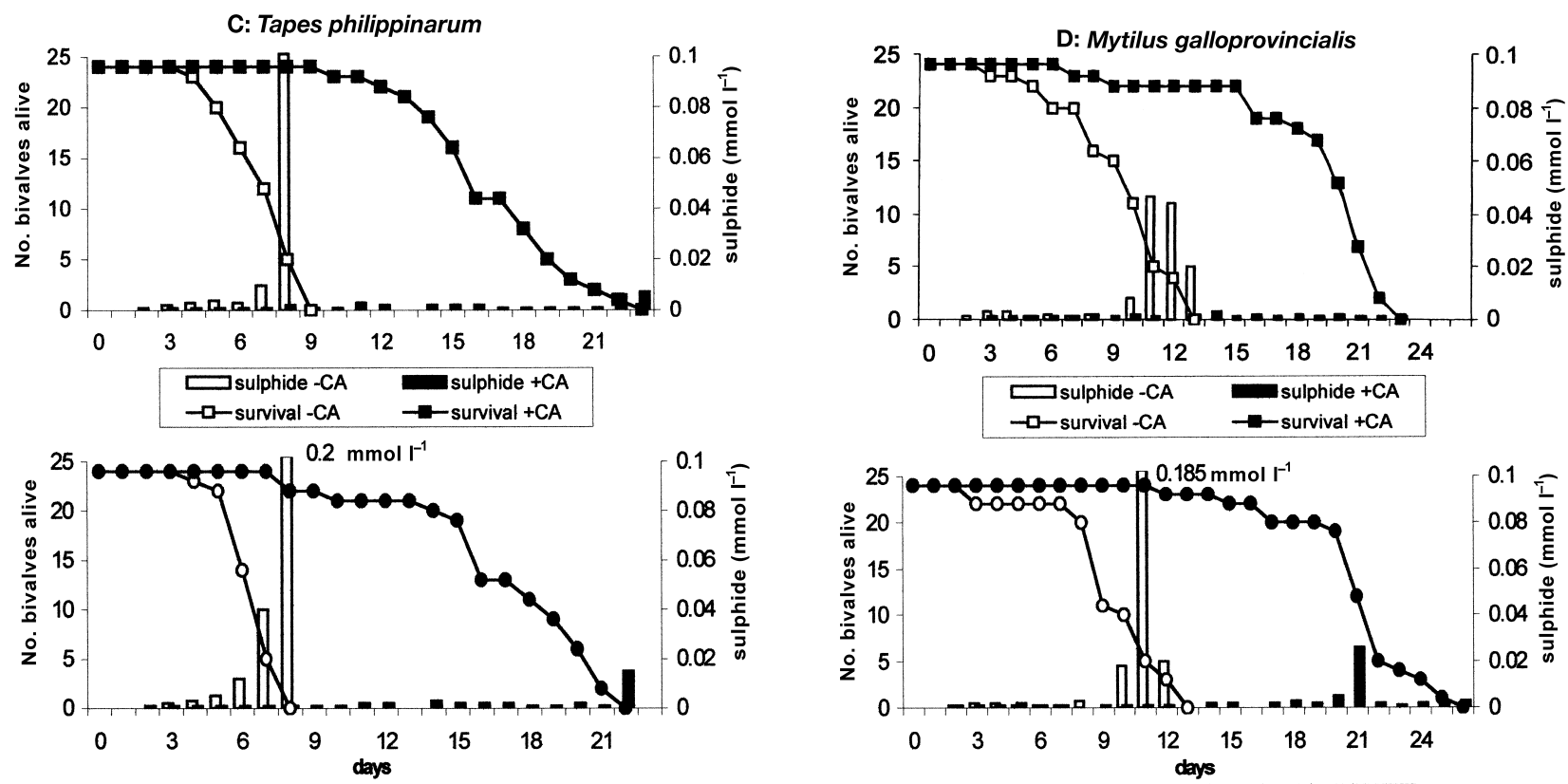

$\square$ suphide $-C A+T R S \square$ suphide +CA + TRIS $\rightarrow$ sunival-CA+TRS $\rightarrow$ survival +CA+TRIS

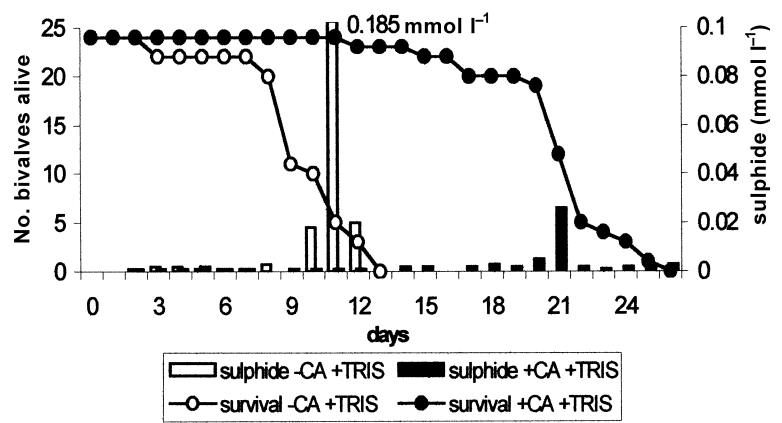

Fig. 5. Scapharca inaequivalvis, Venus gallina, Tapes philippinarum and Mytilus galloprovincialis. Survival of bivalves and accumulation of sulphide in non-buffered (upper graph) and Tris-buffered (+Tris; lower graph) anoxic seawater in the absence $\left(-\mathrm{CA}\right.$; open symbols) or presence $\left(+\mathrm{CA}_{i}\right.$ closed symbols) of chloramphenicol. The media were changed every $24 \mathrm{~h}$; temperature was $18^{\circ} \mathrm{C}$

kedly delayed sulphide formation and, with the exception of Venus gallina (without Tris), caused a decrease in the maximum concentrations reached (Fig. 5).
Except for the first 24 to $48 \mathrm{~h}$, the anaerobic nonbuffered incubations caused, for all species, a drop in the $\mathrm{pH}$ of the incubation medium of 1 to 2 units during 

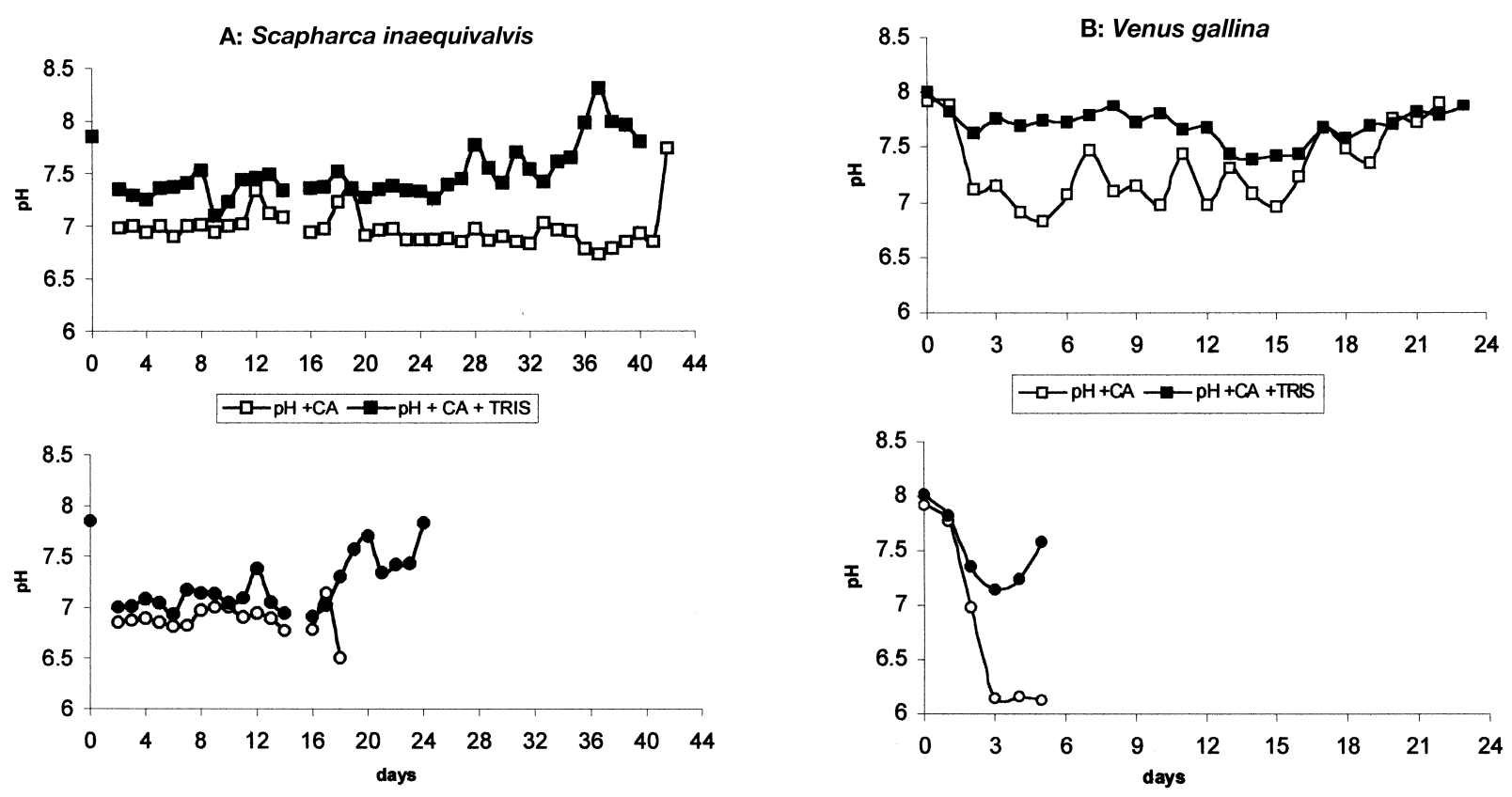

$-\mathrm{O}-\mathrm{pH}-\mathrm{CA} \rightarrow \mathrm{pH}-\mathrm{CA}+\mathrm{TRIS}$
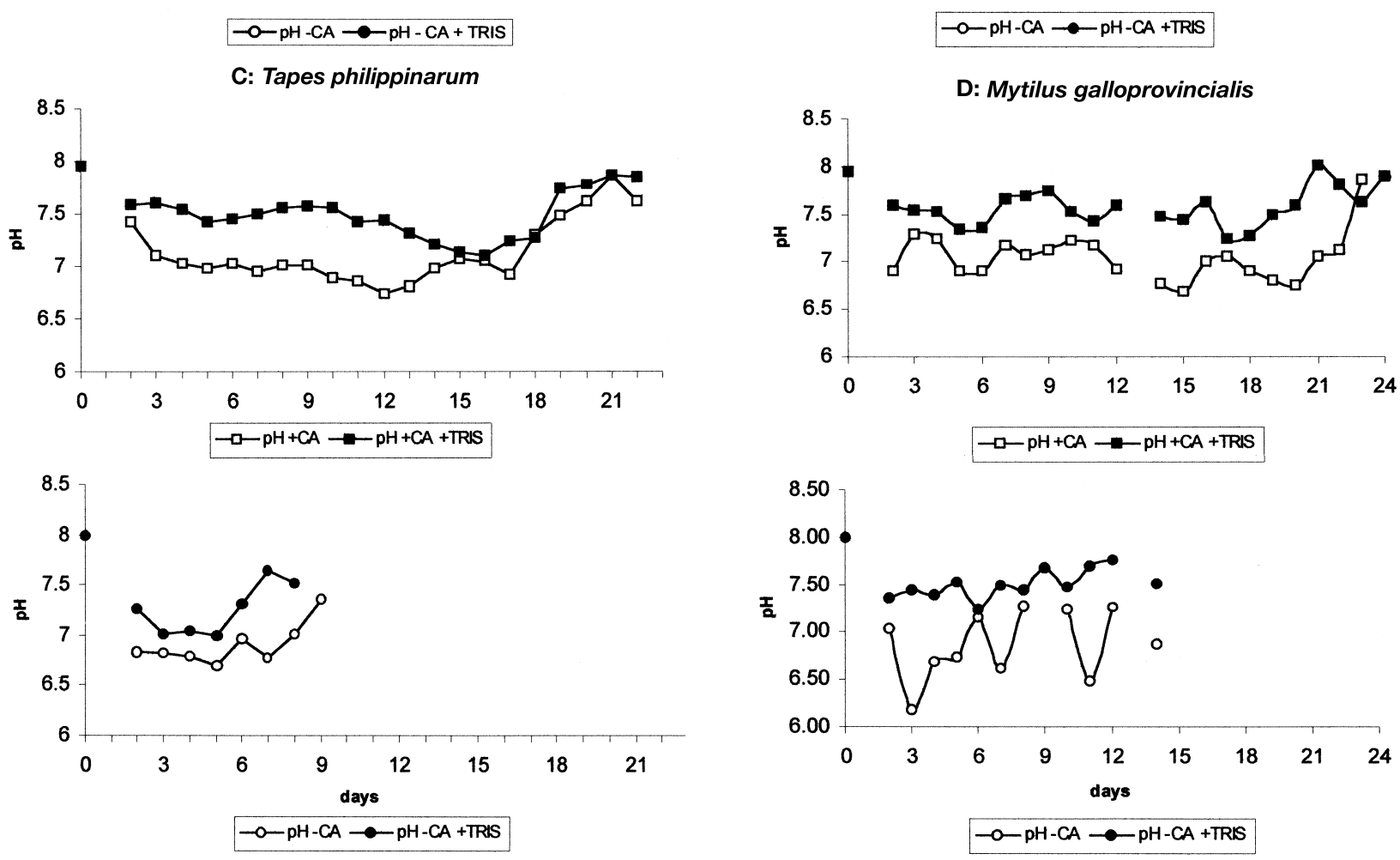

Fig. 6. Scapharca inaequivalvis, Venus gallina, Tapes philippinarum and Mytilus galloprovincialis. Changes in $\mathrm{pH}$ of nonbuffered (open symbols) and Tris-buffered (+Tris; closed symbols) anoxic seawater in the presence (+CA; upper panel) or absence $(-\mathrm{CA}$; lower panel)) of chloramphenicol, in survival experiments shown in Fig. 5

the $24 \mathrm{~h}$ between water renewal (Fig. 6), but only when the number of survivors was $\geq 80 \%$. With fewer individuals, the drop in $\mathrm{pH}$ was smaller. For the 3 infaunal species, the addition of Tris buffer or the antibiotic decreased acidification, while both added simultaneously acted synergistically. However, under no condition was the drop in $\mathrm{pH}$ completely prevented. For Mytilus galloprovincialis, the addition of the buffer 
reduced the drop in $\mathrm{pH}$, but chloramphenicol had no effect on the acidification of the medium (Fig. 6D).

For Venus gallina, Mytilus galloprovincialis and Tapes philippinarum, buffering by Tris had no significant effect on survival time (Fig. 5B,C,D, Table 1). For Scapharca inaequivalvis, there was a small but significant difference. In the absence of chloramphenicol, Tris had a positive effect, in the presence of the antibiotic a negative effect (Fig. 5A, Table 1).

\section{Chloramphenicol, Tris buffer and sulphide}

In this experiment, the Tris buffer $(20 \mathrm{mM})$ was able to maintain the $\mathrm{pH}$ near to the value to which the media were adjusted. Without chloramphenicol, the $\mathrm{pH}$ of the seawater control was 7.9 after $7 \mathrm{~d}$; for the media containing Scapharca inaequivalvis, Venus gallina and Mytilus galloprovincialis it was 7.7, 7.6 and 7.9 respectively. When chloramphenicol was added, the $\mathrm{pH}$ in all cases lay between 7.8 and 7.9. At Day 22, the corresponding values were 7.9 for seawater and 7.0, 7.2 and 7.4 for the media with bivalves; when chloramphenicol was added, these values were 7.9 and 7.8 , 7.6 and 7.9 .

The initial concentration of $\sim 0.4 \mathrm{mmol} \mathrm{l}^{-1}$ sulphide decreased after $24 \mathrm{~d}$ in the seawater controls to 0.29 (without chloramphenicol) and $0.31 \mathrm{mmol} \mathrm{l}^{-1}$ (with chloramphenicol). Also, in all media with bivalves, there was a decrease in the sulphide concentration which, however, never dropped below $0.22 \mathrm{mmol} \mathrm{l}^{-1}$. When the bivalves were dying, there was an increase in sulphide concentration, especially in the absence of chloramphenicol (Fig. 7).

The results show clearly that the presence of sulphide in both the control and the experimental groups did not influence the relative $\mathrm{LT}_{50}$ increase caused by the antibiotic (Fig. 7, Table 2). For the 3 species tested, the degree of $\mathrm{LT}_{50}$ increase corresponded well with that in the previous experiment (Table 1). The absolute values for $\mathrm{LT}_{50}$ in this experiment were slightly higher for Mytilus galloprovincialis and Venus gallina. This was possibly the result of a larger medium-to-animal ratio and less handling of the bivalves (no daily

Table 2. Scapharca inaequivalvis, Venus gallina and Mytilus galloprovincialis. Effect of chloramphenicol (CA) in the presence of Tris $(20 \mathrm{mM})$ and $\mathrm{H}_{2} \mathrm{~S}(0.4 \mathrm{mM})$ on $\mathrm{LT}_{50}$ values (d) of 3 bivalve species

\begin{tabular}{|lcc|}
\hline Species & $+\mathrm{CA}$ & $-\mathrm{CA}$ \\
\hline S. inaequivalvis & 22.2 & 8.6 \\
V. gallina & 22.3 & 4.1 \\
M. galloprovincialis & 21.7 & 11.9 \\
\hline
\end{tabular}

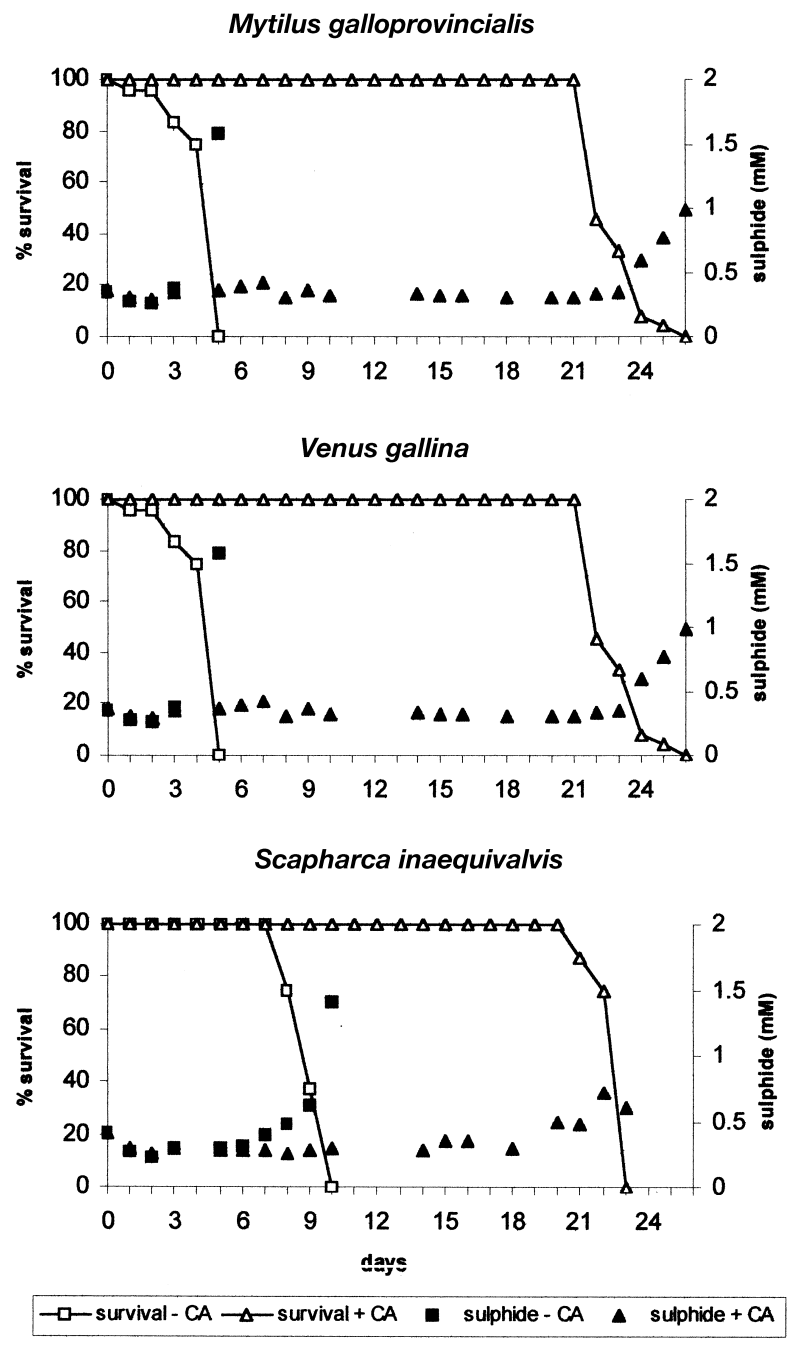

Fig. 7. Mytilus galloprovincialis, Venus gallina and Scapharca inaequivalvis. Survival $(\square, \Delta)$ and sulphide concentrations $(\boldsymbol{\square}, \mathbf{\Delta})$ in anoxic, Tris-buffered seawater containing sulphide (initial $0.4 \mathrm{mM})$ of controls $\left(-\mathrm{CA}_{;} \square, \boldsymbol{\square}\right)$ and chloramphenicolexposed $\left(+\mathrm{CA}_{i} \Delta, \mathbf{\Delta}\right)$. The incubation medium was not changed during the experiment

medium renewal). This is in sharp contrast with the result for Scapharca inaequivalvis, for which the median survival time both in the presence and absence of chloramphenicol appeared to be strongly negatively affected by the added sulphide. This agrees with the previous result on the effect of sulphide on survival time of $S$. inaequivalvis and V. gallina, and indicates that, like V. gallina, M. galloprovincialis is insensitive to the presence of sulphide in the medium.

\section{DISCUSSION}

Laboratory and field studies have demonstrated the applicability of anoxic survival as an early warning 
indicator of contaminant-induced stress. Following chronic exposure to sublethal toxicant concentrations, anoxic survival is generally decreased (de Zwaan \& Eertman 1996). Also, exposure of Scapharca inaequivalvis to $100 \mathrm{ppb} \mathrm{Cd}$ for $2 \mathrm{wk}$ prior to transfer to anoxic seawater resulted in a decrease in anoxic survival time. However, when $S$. inaequivalvis (collected from muddy sediment) and Venus gallina were exposed to a 5 times higher dose of $\mathrm{Cd}$ under anoxic conditions, survival time increased by a factor of 2 (Figs. 1 \& 2). Blackening of the bivalve shells was observed in anoxic water in the absence of $\mathrm{Cd}$, but not when $\mathrm{Cd}$ was present. The blackening of the shells in the controls points to the generation of sulphide by microbial activity, which seemed to be inhibited by $\mathrm{Cd}$. In the case of the controls, the microbial release of sulphide (and other noxious products) may have caused adverse effects on $\mathrm{LT}_{50}$. For $S$. inaequivalvis collected from sandy sediment, shell blackening was rarely observed, pointing to less contamination by sulphide-producing bacteria. In addition, the lower incubation temperature of $11^{\circ} \mathrm{C}$ (opposed to $17^{\circ} \mathrm{C}$ ) for the 'muddy' incubated clams probably slowed down bacterial proliferation.

The blackening of shells was reduced in all experiments in which bacterial growth was reduced, either by natural factors correlated with the location of growth (Fig. 1: upper graph) or by addition of antibiotics. The possibility that sulphide produced by bacteria might have abiotically complexed with Cd can be ruled out. First, the added concentration of $\mathrm{Cd}(500 \mu \mathrm{g}$ $\mathrm{l}^{-1}=\sim 4 \mu \mathrm{mol} \mathrm{l}^{-1}$ ) is at least 1 order of magnitude lower than the spontaneously formed concentrations of sulphide (see e.g. Figs. 3 \& 5). Second, a comparable positive effect on survival time was obtained when Scapharca inaequivalvis was incubated in the presence of $500 \mathrm{ppb} \mathrm{Cd}$ for $2 \mathrm{wk}$ prior to the anoxic survival test in Cd-free anoxic seawater (results not shown).

Shell blackening is caused by precipitation of a metal and sulphide, and absence of discolouration points to inhibition of sulphide formation. This was an indication that the adverse effect on anoxia tolerance is caused by the growth of anaerobic bacteria. Further studies, in which a broad-band antibiotic (chloramphenicol) was used to delay bacterial growth confirmed strong correlations between the occurrence of bacteria, monitored as sulphide production, and increased mortality of bivalves. In a pilot study, we also obtained positive effects on survival with oxytetracycline hydrochloride, streptomycin sulphate and penicillin-G (separate and in combination). All 4 bivalve species showed strongly improved anoxic survival times in its presence (2- to 4 -fold: Table 1). Especially for Venus gallina, but also for Scapharca inaequivalvis, the benefit was higher than with $\mathrm{Cd}$. Without antibiotic, sulphide accumulation was observed for all spe- cies (Fig. 5). In the case of the blood clam, the presence of dead individuals was no prerequisite for the formation of sulphide. From Day 2 up to Day 13, there was an exponential increase in sulphide concentration (up to $1.35 \mathrm{mmol} \mathrm{l}^{-1}$ ), whereas the first clam died on Day 8 (Fig. 5A: upper curve). Accumulation not only began much earlier than for the other species, but also reached much higher concentrations. The antibiotic was able to postpone the accumulation of sulphide considerably, but did not finally prevent it. Seemingly protected by the presence of the bivalve, a significant population of sulphate-reducing bacteria was able to survive in the presence of chloramphenicol. As in other bivalves, this apparently chloramphenicol-resistant population increased when the bivalves began to die, and was removed from the flask together with the dead individuals. However, we cannot conclude from these data that sulphide caused the death of the bivalves, because mortality in the presence of sulphide (Figs. 4 \& 7) did not increase at the onset of sulphide treatment, but only when endogenous sulphideproduction indicated excessive growth of sulphatereducing bacteria. Although we cannot exclude the possibility that a small number of chloramphenicolresistant sulphide-producing bacteria were associated with the bivalves initially, it is more likely that these bacteria proliferate in places where access of the antibiotic is limited, e.g. possibly in biofilms or in (necrotic) tissue of the bivalve. Decomposition of the antibiotic can be ruled out, as it was added freshly each day during renewal of the medium.

The responsible micro-organisms must have been introduced with the bivalves and not with the seawater. This follows from the fact that progressively increasing levels of sulphide could be detected in the incubation medium (Fig. 5), despite the fact that the medium was exchanged daily. It also explains why the levels reached a maximum and decreased again when the number of bivalves decreased through mortality. Anoxia obviously induced the proliferation of bacteria, which remained associated with the bivalves. Regular renewal of the incubation medium in order to avoid accumulation of toxic metabolites (see e.g. Oeschger \& Pedersen 1994, Jahn \& Theede 1997) may therefore not be effective.

Both the bivalves and micro-organisms must have been responsible for acidification of the medium (Figs. 4 \& 6). Acidification was strongest in the absence of the antibiotic and the buffer. Acidification in the presence of the antibiotic must have been mainly due to the excretion of acids produced by anaerobic catabolism of the bivalves. Possible candidates are $\mathrm{CO}_{2}$, acetate and propionate (de Zwaan et al. 1991). The $\mathrm{pH}$ values for all incubations ranged between 6 and 8 . A lower $\mathrm{pH}$ value had no or inconsistent effects on sur- 
vival time. The positive result of chloramphenicol on anoxic survival was therefore independent of its effect on acidification.

In the final experiment (Fig. 7) the main objective was to investigate the extent to which the positive effect of chloramphenicol on anoxic survival could be counteracted by sulphide. Therefore, a relative high dose of sulphide $(400 \mu \mathrm{M})$ was added to both the control and the experimental groups. Chloramphenicol was added only to the experimental group. As expected, Venus gallina again showed a much longer anoxic survival time as a result of chloramphenicol addition, despite the addition of sulphide. We have already shown that this organism was insensitive to a high dose of sulphide (Fig. 4). Also in the case of Scapharca inaequivalvis and Mytilus galloprovincia lis, the relative increase in survival time due to chloramphenicol remained in combination with a high dose of sulphide (Fig. 7). Only for the blood clam was the absolute survival time of both the control and the experimental groups strongly reduced. For this species, suppression of sulphide generation can therefore explain part of the positive action of the antibiotic (and the high dose of $\mathrm{Cd}$ ). This means that additional (blood clam) compounds or compounds other than sulphide must have been responsible for the adverse effects on survival of the controls, and/or that bacteria acted directly in disrupting the organism.

It is intriguing that Scapharca inaequivalvis showed the highest sulphide production indicating association with the largest population of sulphate-reducing bacteria. Furthermore, this bivalve apparently provided protection to sulphate-reducing bacteria against chloramphenicol before it died (Fig. 5). It is tempting to speculate that this bivalve has a benefit from these bacteria, but the mechanism is not obvious. In our assays, $S$. inaequivalvis was the only bivalve that exhibited a significant decrease in survival time in the presence of sulphide (Figs. $4 \& 7$ ), a major product of sulphate-reducing bacteria. Furthermore, the latter are obligatory anaerobic, heterotrophic bacteria, while all bacterial symbionts described for diverse marine invertebrates are chemoautotrophic sulphide (or methane)-oxidising bacteria that simultaneously provide, food and sulphide detoxification (Distel 1998). It has been assumed that a fairly high concentration of sulphide is a prerequisite for bivalve association with symbiotic sulphur bacteria (i.e. deep-sea hydrothermic vents, sewage outfalls and seagrass beds). Dando et al. (1985) showed the presence of sulphur-oxidising bacteria in the gill of the bivalve Myrtea spinifera living in muddy sand of a Norwegian fjord, but the sediment in which this bivalve lives has a very low concentration of free sulphide. This species possesses haemoglobin in its gill tissue, which has a high affinity for oxygen but lacks red blood cells. The blood clam $S$. inaegiuvalvis belongs to the Arcidae family which, unlike other molluscs, contains haemoglobin-laden erythrocytes (Chiancone et al. 1981). Also, its gills are red-coloured due to the presence of intracellular haemoglobin. Preliminary studies (by A. Hernandez at the Netherlands Institute of Ecology) of the bacterial populations associated with $S$. inaegiuvalvis have shown that sulphideoxidising and sulphate-reducing bacterial populations occur not only in externally association with apparently healthy individuals of this bivalve, but also appear to cohabit in different tissues, even in the blood system. Possibly clams from low-sulphide sediments need to host sulphate-reducing bacteria to provide sulphide in order to profit from symbiosis with sulphide-oxidising bacteria. The beneficial effect of chloramphenicol under anoxic conditions (Figs. 4, 5 \& 7) may indicate that opportunistic bacteria, which become pathogenic under severe stress, exist among the associated bacteria. Further studies on the quantification and identification of dominant species among associated bacteria is part of our current research program.

In conclusion, it is obvious that especially during prolonged anoxia and at high temperatures, the study of anoxic resistance in a closed system or even in a system with daily water changes may result in strongly underestimated survival times due to bacterial proliferation. Anoxic survival is therefore no reliable biological-response parameter for assessing water quality when the contaminants present display bacteriostatic effects. The biotic formation of sulphide plays a minor (blood clam) or no role in their adverse effect on survival. Studies on stoichiometric aspects of metabolism, including release of end-products, may also lead to artefacts. In such studies the addition of antibiotics should be considered. They are often applied in research on the anaerobic metabolism of worms (see e.g. Zebe 1975, Surholt 1977, Bestwick et al. 1989) and midge larvae (Englisch et al. 1982), but in general not in research on other aquatic invertebrates. There is a risk that the antibiotic itself interferes with metabolism. We sometimes observed for Scapharca inaequivalvis the production of mucus in response to the presence of chloramphenicol in the water. Despite the remarkable positive effect of this antibiotic on survival, we cannot therefore exclude the possibility that the established high $\mathrm{LT}_{50}$ values for anoxia still underestimate the capacity of bivalves to survive anoxia.

Acknowledgements. The authors would like to thank Anneliese Ernst and Lucas J. Stal for critical comments on the manuscript. Publication number 2672 of the Netherlands Institute of Ecology, Centre for Estuarine and Coastal Ecology, Yerseke. 


\section{LITERATURE CITED}

Bestwick BW, Robbins IJ, Warren LM (1989) Metabolic adaptations of the intertidal polychaete Cirriformia tentaculata to life in an oxygen-sink environment. J Exp Mar Biol Ecol 125:193-202

Brooks SPJ, de Zwaan A, van den Thillart G, Cattani O, Cortesi P, Storey KB (1991) Differential survival of Venus gallina and Scapharca inaequivalvis during anoxic stress: covalent modification of phosphofructokinase and glycogen phosphorylase during anoxia. J Comp Physiol Biochem Syst Environ Physiol 161:207-212

Chiancone E, Vecchini P, Verzili D, Ascoli F (1981) Dimeric and tetrameric hemoglobins from the mollusc $S$. inaequivalvis. J Mol Biol 152:577-592

Cortesi P, Cattani O, Vitali G, Carpené E, de Zwaan A, van den Thillart G, Roos J, van Lieshout G, Weber RE (1992) Physiological and biochemical responses of the bivalve Scapharca inaequivalvis to hypoxia and cadmium exposure: erythrocytes versus other tissues. Sci Total Environ (Suppl) 1992:1041-1053

Dando PR, Southward AJ, Terwilliger NB, Terwilliger RC (1985) Sulphur-oxidising bacteria and haemoglobin in gills of the bivalve Myrtea spinifera. Mar Ecol Prog Ser 23:85-98

de Zwaan A, Eertman RHM (1996) Anoxic or aerial survival of bivalves and other euryoxic invertebrates as a useful response to environmental stress - a comprehensive review. Comp Biochem Physiol 113C:299-312

de Zwaan A, Skjoldal HR (1979) Anaerobic energy metabolism of the scavenging isopod Cirolina borealis (Lilljeberg). J Comp Physiol 129:327-331

de Zwaan A, de Bont AMT, Verhoeven A (1982) Anaerobic energy metabolism in isolated adductor muscle of the sea mussel Mytilus edulis L. J Comp Physiol 149:137-143

de Zwaan A, Cortesi P, van den Thillart G, Roos J, Storey KB (1991) Differential sensitivities to hypoxia by two anoxiatolerant marine molluscs: a biochemical analysis. Mar Biol 111:343-351

de Zwaan A, Cortesi P, Cattani O (1995) Resistance of bivalves to anoxia as a response to pollution-induced environmental stress. Sci Total Environ 171:121-125

Distel DL (1998) Evolution of chemoautotrophic endosymbiosis in bivalves. BioScience 48:277-286

Eertman RHM, de Zwaan A (1994) Survival of the fittest: resistance of mussels to aerial exposure. In: Kramer KJM (ed) Biomonitoring of coastal waters and estuaries. CRC Press, Boca Raton, p 269-284

Englisch H, Opalka B, Zebe E (1982) The anaerobic metabolism of the larvae of the midge Chaoborus crystallinus. Insect Biochem 12:149-155

Felder DL (1979) Respiratory adaptations of the estuarine mud shrimp, Callianassa jamaicense (Schmitt 1935) (Crustacea, Decapoda, Thalassinidea). Biol Bull 157:125-137

Frank C (1983) Ecology, production and anaerobic metabolism of Chironomus plumosus L. larvae in a shallow lake. II. Anaerobic metabolism. Arch Hydrobiol 96:354-362

Gamenick I, Jahn A, Giere O (1996) Hypoxia and sulphide as structuring factors in a macrozoobenthic community on the Baltic Sea shore: colonisation studies and tolerance experiments. Mar Ecol Prog Ser 144:73-85

Editorial responsibility: William Stickle (Contributing Editor), Baton Rouge, Louisiana, USA
Ghisotti F, Rinaldi E (1976) Osservazioni sulla popolazione del Scapharca insediatasi in questi ultimi anni su un tratto di littorale romagnoto. Conchiglie (Milan) 12:183-195

Hamilton MA, Russo RC, Thurston RV (1977) Trimmed Spearman-Karber method for estimating median lethal concentrations in toxicity bioassays. Environ Sci Technol Libr 11: $714-719$

Hummel H, de Wolf L, Zurburg W, Apon L, Bogaards RH, van Ruitenberg M (1989) The glycogen content in stressed marine bivalves: the initial absence of a decrease. Comp Biochem Physiol 94B:729-733

Jahn A, Theede H (1997) Different degrees of tolerance to hydrogen sulphide in populations of Macoma balthica (Bivalvia, Tellinidae). Mar Ecol Prog Ser 154:185-196

Kaplan EL, Meier P (1958) Nonparametric estimation from incomplete observations. J Am Stat Assoc 53:457-481

Llansó RJ, Diaz RJ (1994) Tolerance to low dissolved oxygen by the tubicolous polychaete Loimia medusa. J Mar Biol Assoc UK 74:143-148

Oeschger R (1990) Long-term anaerobiosis in sublittoral marine invertebrates from the Western Baltic Sea: Halicryptus spinulosus (Priapulida), Astarte borealis and Arctica islandica (Bivalvia). Mar Ecol Prog Ser 59:133-143

Oeschger R, Pedersen TF (1994) Influence of anoxia and hydrogen sulphide on the energy metabolism of Scrobicularia plana (da Costa) (Bivalvia). J Exp Mar Biol Ecol 184: 255-268

Oeschger R, Theede H (1988) Use of biochemical features of macrobenthic species as indicators of long-term oxygen deficiency. Kiel Meeresforsch 6:99-110

Surholt B (1977) Production of volatile fatty acids in the anaerobic carbohydrate catabolism of Arenicola marina. Comp Biochem Physiol 58B: 147-150

Svenson A (1980) A rapid and sensitive spectrophotometric method for determination of hydrogen sulfide with $2,2^{1}$ dipyridyl disulfide. Anal Biochem 107:51-55

Truesdale VH (1971) A modified spectrophotometric method for the determination of ammonia (and amino-acids) in natural waters, with particular reference to sea water. Analist 96:584-590

van den Thillart G, van Lieshout G, Storey K, Cortesi P, de Zwaan A (1992) Influence of long-term hypoxia on the energy metabolism of the haemoglobin-containing bivalve Scapharca inaequivalvis: critical $\mathrm{O}_{2}$ levels for metabolic depression. J Comp Physiol B 162:297-304

Weber RE (1990) Effects of mercury on functional properties of haemoglobins from the bivalve mollusc Scapharca inaequivalvis. J Exp Mar Biol Ecol 144:39-48

Weber RE, Lykke-Madsen M, Bang A, de Zwaan A, Cortesi P (1990) Effects of cadmium on anoxic survival, haematology, erythrocytic volume regulation and haemoglobinoxygen affinity in the marine bivalve Scapharca inaequivalvis. J Exp Mar Biol Ecol 14:29-38

Weber RE, de Zwaan A, Bang A (1992) Interactive effects of ambient copper and anoxic, temperature and salinity stress on survival and hemolymph and muscle tissue osmotic effectors in Mytilus edulis. J Exp Mar Biol Ecol 159: 135-156

Zebe E (1975) In vivo-Untersuchungen über den GlucoseAbbau bei Arenicola marina. J Comp Physiol 101:133-145

Submitted: May 18, 2000; Accepted: July 11, 2000

Proofs received from author(s): January 29, 2001 